DOI https://doi.org/10.30525/978-9934-588-80-8-2.16

\title{
KEY PRINCIPLES OF CONTINUOUS PROFESSIONAL EDUCATION IMPLEMENTATION
}

\author{
Moroz O. L. \\ Candidate of Philological Sciences, Associate Professor, \\ Senior Lecturer at the English Language Department for Deck Officers \\ Kherson State Maritime Academy \\ Kherson, Ukraine
}

Nowadays dynamic changes in people's lifestyle demand for the changes and renovations in the content, methodology and organization of both secondary and higher education. So, one of the important needs of today's education is considered to be its quality improvement. Scientists recognize the necessity to upgrade and modernize educational system. The conceptual ideas for this can be found in the works by V. Boichuk, V. Bykov, I. Ziaziun, V. Kremen, N. Nychkalo, S. Sysoieva and others. According to them the main task of education system modernization is not the drastic change of what we have had before but rather is the renovation and improvement of teaching approaches and methods so that our educational system may reach European standards and thus to satisfy the labor market demands [1, p. 197]. Due to the integration and globalization processes today there is a need in graduates who comply with the international standards of professional training and, for this reason, we can spot the internalization of higher educational institutions operation.

In state statutory documents it is emphasized that higher education today must provide for the highly qualified, competent, active and flexible personnel training, providing for the professionals capable of creative activity and professional development $[3 ; 6]$.

Fast changes and development of all spheres of human life make it not enough today just to acquire some package of ready-made knowledge while studying at higher educational institutions. What we need instead is to teach students how to develop their knowledge, skills and competencies along with the changing professional environment. This need was the basis for continuous learning concept development in the second half of the XX century. State national programme «Education» [2] stipulates the further development of continuous education among the most important tasks in Ukraine. Different aspects of the system performance were discussed in the works by A. Aleksiuk, I. Ziaziun, I. Lerner, N. Nychkalo, P. Pidkasystyi, O. 
Plakhotnyk, V. Fediaieva and others. It was established that the system of continuous (or life long learning) may be implemented by means of three major types of education: formal, nonformal and informal.

Speaking about professional training of future seafarers we would like to concentrate here on the basic principles of formal continuous education implementation. According to the National Doctrine of Ukrainian education system development in the XXI century [5], there should be appropriate conditions provided for the implementation of basic continuous education principles among which is the transition towards multi-leveled educational approach. If we consider continuous education as a system, we may argue that its effectiveness depends upon each of the components inside the system and the way the components are organized and structured into a single unity. We believe that educational establishments of different levels of accreditation maybe considered as the key elements of continuous professional education system which meet the requirements of each individual student in accordance with his/her desires, capabilities and needs. But, at the same time, we claim that if the elements of the system operate in isolation and independently from each other there is no chance such operation promotes the integration and succession of the components that, in turn, leads to the failure of the whole system.

So, we suggest that for the best realization of basic European principles of professional education development it would be a great idea to unite professional educational institutions of different levels into academic complexes. For example, in Kherson State Maritime Academy for the effective professional training of future seafarers it has been established the academic complex «lyceum - college - academy». The implementation of the multi-leveled approach when teaching Maritime English complies with the Ukrainian national legislation which defines the qualification levels such as qualified personnel, associate, bachelor and master. At the same time this approach meets the requirements of the STCW Convention as for the defining the competencies at different levels of responsibility: support, operational and managerial ones [4].

For the work of the complex to be effective the adherence to the key principles of continuous professional education implementation is crucial. The thorough analysis of scientific research papers and our own experience of teaching Maritime English allow for the highlighting the following key principles.

1. The formation of coordination council with the aim to synchronize the work of all English language departments that are acting in the academic complex. The representatives of English language departments from the Maritime Lyceum, Maritime College and Maritime Academy work together 
on the key issues of the teaching process to make sure we all use the same approaches, establish the same goals and priorities, meet the same requirements. The head of the coordination council is responsible for the work organization, monitoring the implementation of decisions taken and guiding the English language teachers in the same direction. As a result, it allow for the cooperation between the teaching staff, working out the best strategies and thus reaching our shared objective: professional training of qualified, competent and highly competitive specialists.

2. The development of comprehensive and coherent syllabus to provide for the adhering to the succession principle. In the academic complex, students may start their education in any of the three educational establishments suggested (lyceum, college or academy) with the possibility for future transition to the others. For example, after graduating lyceum and receiving the diploma of qualified personnel, students may wish to transfer to the Maritime College and continuo the education for the next academic level - associate degree. Later they have a chance of entering the Academy for obtaining bachelor and master degree. So, to avoid the repetition or omission of any relevant and crucial professional information, it is highly important to synchronize all syllabuses so that all modules and topic are logically correlated and complementary.

3. Regular conduct of FDS (Faculty Development Sessions) for the English language teachers from all English language departments that are acting in the academic complex. These are practical workshops where newly joined personnel and everyone who is interested are trained how to teach maritime students in accordance with the principles of the communicative and competency-based approaches which are recognized as the fundamental ones in the complex. During such sessions English language teachers organize practical task-based activities to demonstrate how to implement this or that communicative strategy, method or activity, how to organize a specific stage of a lesson, how to formulate the objective of the lesson so that it complies with the requirements of the approaches mentioned and the like. Topic for such FDS are pre-planned in the beginning of each academic year after consulting the teachers about their needs: what they experience difficulties with, what they want to get a deeper understanding of, etc. Regular conduct of FDS allows for the same teaching manner in all three educational establishments of the academic complex thus enabling easy adaptation of students who continue their professional training at different levels and stages.

So, we may conclude that the development of continuous professional education system is a requirement of today as it can enable the individualized professional development of a person promoting his/her 66 
competency and competitiveness thus promoting social and economical well-being of Ukraine. It is also the way of integrating Ukrainian professsional education into European and world Common Education Space.

\title{
References:
}

1. Бойчук В. М. Теоретичні і методичні основи художньо-графічної підготовки майбутнього вчителя технологій : дис. ... д-ра пед. наук : 13.00.04. Київ, 2016. 873 с.

2. Державна національна програма «Освіта» («Україна XXI століття»). URL: https://zakon.rada.gov.ua/laws/show/896-93-\%D0\% BF\# Text (дата звернення: 07.09.2020)

3. Закон України «Про вищу освіту». URL: https://zakon.rada.gov.ua/ laws/show/1556-18\#Техt (дата звернення: 07.09.2020)

4. Мороз О.Л. Особливості формування професійно-орієнтованої комунікації майбутніх фахівців морського флоту в умовах неперервної освіти. Молодий вчений. 2019. Вип. 7.2 (71.2). С. 118-121.

5. Національна Доктрина розвитку освіти України у XXI столітті URL: https://zakon.rada.gov.ua/laws/show/347/2002\#Техt (дата звернення: 07.09.2020)

6. Національна стратегія розвитку освіти в Україні на 20122021 роки. URL: http://oneu.edu.ua/wp-content/uploads/2017/11/nsro_ 1221.pdf (дата звернення: 07.09.2020)

DOI https://doi.org/10.30525/978-9934-588-80-8-2.17

\section{THEORETICAL ASPECT OF THE USE OF PROJECT} TRAINING TECHNOLOGIES IN THE EDUCATIONAL PROCESS

\author{
Morozova M. M. \\ Candidate of Pedagogical Sciences, \\ Luhansk Taras Shevchenko National University \\ Starobilsk, Luhansk Oblast, Ukraine
}

The work aims to reveal the features of the implementation of design technology based on the coverage of the essential characteristics of the concepts «project technology», «project method», «design», «project», and «project activity».

Describing the concept of «project technology», we point out that this is a training technology, the implementation of which expands the possibilities 